\title{
Pyrazolate-Based Dinuclear $\alpha$-Diimine-Type Palladium(II) and Nickel(II) Complexes - a Bimetallic Approach in Olefin Polymerisation
}

\author{
Gilles Noël, ${ }^{\mathrm{a}}$ Jens C. Röder, ${ }^{\mathrm{b}, \mathrm{d}}$ Sebastian Dechert, ${ }^{\mathrm{a}}$ Hans Pritzkow, ${ }^{\mathrm{b}}$ Lars Bolk, ${ }^{\mathrm{c}}$ \\ Stefan Mecking, ${ }^{\mathrm{c}}$ Franc Meyer ${ }^{\mathrm{a}, *}$
}

a Institut für Anorganische Chemie, Georg-August-Universität, Tammannstr. 4, 37077 Göttingen, Germany Fax: (+49)-551-39-3063, e-mail: franc.meyer@chemie.uni-goettingen.de

b Anorganisch-Chemisches Institut, Ruprecht-Karls-Universität, INF 270, 69120 Heidelberg, Germany

c Fachbereich Chemie, Universität Konstanz, Universitätsstr. 10, 78457 Konstanz, Germany

d New address: Chemetall GmbH, Trakehner Str. 3, 60487 Frankfurt, Germany

Abstract: A series of compartmental pyrazole/imine
dinucleating ligands $\mathbf{H L}^{1}-\mathbf{H L}^{4}$ have been prepared
with different backbone substitutents and different
steric bulk of the appending arylimine groups, and
two of them have been structurally characterised.
With $\mathrm{PdCl}_{2}$ all ligands form the anticipated pyrazo-
late-bridged bimetallic complexes $\mathrm{LPd}_{2} \mathrm{Cl}_{3}(\mathbf{1 a}-\mathbf{4 a})$
that feature square-planar metal ions, as is confirmed
by the $\mathrm{X}-$ ray crystallographic analyses of $\mathrm{L}^{1} \mathrm{Pd}_{2} \mathrm{Cl}_{3}$
$(\mathbf{1 a})$ and $\mathrm{L}^{3} \mathrm{Pd}_{2} \mathrm{Cl}_{3}(\mathbf{3 a}) . \mathrm{With} \mathrm{NiBr}_{2}(\mathrm{dme})$, however,
oligonuclear systems $\left[\mathrm{LNi}_{2} \mathrm{Br}_{3}\right]_{\times}(\mathbf{1 b}-\mathbf{4 b})$ are formed
according to mass spectrometric findings, which is
corroborated by the crystallographic structure of
$\left[\mathrm{L}^{3} \mathrm{Ni}_{2} \mathrm{Br}_{3}\right]_{3}$. Complexes $\mathbf{1 a}-\mathbf{4 a}$ can be described as bi-
metallic versions of Brookhart-type $\alpha$-diimine palladi-
um complexes, where dissociation into mononuclear
species is prevented by the dinucleating scaffold and

\section{Introduction}

Since Brookhart et al. introduced nickel and palladium complexes of $\alpha$-diimine ligands ${ }^{[1]}$ with bulky aryl substituents as efficient pre-catalysts for olefin polymerisation ${ }^{[2]}$ these systems and various derivatives thereof have been studied extensively. ${ }^{[3]}$ Most of the catalytic chemistry of such type A compounds is based on the presence of two active coordination sites at the single metal centre, which prompted us to devise novel bimetallic type $\mathbf{B}$ complexes where two adjacent metal ions might work in concert (Scheme 1). The basic concept, i.e., the use of a pyrazolate bridge to (in a formal sense) link two N-based ligand compartments in a preorganised dinucleating scaffold, has been outlined previously the proximate metal ions are suitably positioned to work in concert during substrate transformation. Upon activation of the complexes with MAO and exposure to ethylene, polyethylene is formed. Whereas the palladium complexes display moderate activities, nickel complexes are very active. From structure/activity correlations it is evident that the presence of backbone substitutents at the pyrazolate scaffold as well as bulky ortho aryl substituents is advantageous for polymerisation. Overall, activities of the Ni complexes and the microstructure of the polymer obtained (total branching, $T_{\mathrm{m}}$ and molecular weights) are still rather similar to the data reported previously for mononuclear cationic diimine nickel complexes.

Keywords: dinuclear complexes; $\mathrm{N}$ ligands; nickel; olefin polymerisation; palladium

and has proven successful for the investigation of bimetallic versions of $\mathrm{N}$-donor-functionalised cyclopentadienyl compounds ${ }^{[4]}$ as well as bimetallic versions of classical Werner-type coordination compounds. ${ }^{[5,6]}$

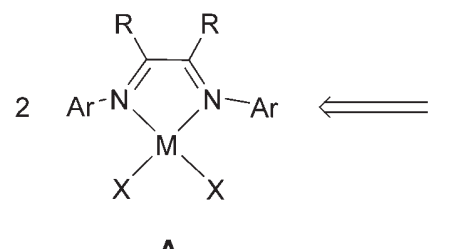

A

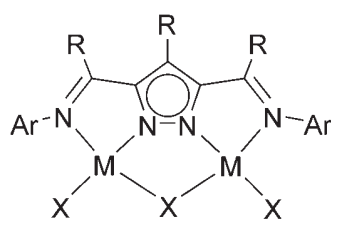

B

Scheme 1. 
A synthetic route to a multidentate pyrazolate ligand $\mathbf{H L}^{3}$ that bears bulky 2,6-diisopropylphenyl substituents at the imine $\mathrm{N}$ atoms and that appears suitable for the preparation of type $\mathbf{B}$ systems has been described recently, ${ }^{[7,8]}$ and a first dinickel(II) complex of this ligand has been communicated. ${ }^{[8]}$ The latter was found to form an unusual hexanuclear aggregate $\left[\mathrm{L}^{3} \mathrm{Ni}_{2} \mathrm{Cl}_{3}\right]_{3}$ in the solid state that incorporates a $\mu_{6}$-chloride ion in the centre of a trigonal prism of nickel(II) ions. Here we report (i) the synthesis of a series of dinucleating pyrazole/ imine ligands with either $\mathrm{H}$ atoms $(\mathrm{R}=\mathrm{H}$, such as in $\left.\mathbf{H L}^{3}\right)$ or more bulky methyl groups $(\mathrm{R}=\mathrm{Me})$ attached to the backbone, and with different steric bulk of the appended aryl groups, (ii) the molecular structures of nickel(II) and palladium(II) complexes of these ligands, and (iii) the results of ethylene polymerisation studies using the new complexes and MAO as a cocatalyst. Potential cooperative effects in such highly preorganised bimetallic complexes may offer new options in metal-mediated catalytic reactions. ${ }^{\left[{ }^{[9]}\right.}$ In particular, few bimetallic catalyst systems have hitherto been used in olefin polymerisation, ${ }^{[10-12]}$ and most of them provide a flexible linker between two Cp-derived entities. ${ }^{[10]}$ In contrast, the present type $\mathbf{B}$ systems offer a highly preorganised dinuclear array in which each subunit closely resembles that of the well-studied Brookhart-type $\alpha$-diimine systems A. Because of the compartmental design of the pyrazolate-based ligand scaffold, the dinuclear arrangement is expected to stay intact under typical conditions for olefin polymerisation (i.e., substitution or abstraction of coligands X upon reaction with MAO cocatalyst). In addition, all accessible coordination sites are directed towards the same side of the bimetallic set-up and are thus favourably positioned for cooperative action.

\section{Results and Discussion}

\section{Synthesis and Structural Characterisation of Ligands}

For the preparation of type I pyrazole-diimine ligands with either $\mathrm{H}$ atoms or methyl groups in the backbone, efficient syntheses based on cheap and commercially available starting materials had to be developed. The pyrazole derivatives I and II with carbonyl substituents in the 3- and 5-positions of the heterocycle were prepared with slight modifications of the procedures reported in the literature ${ }^{[13,14]}$ and were used in the subsequent Schiff base formation (Scheme 2). Proper conditions turned out to be critical in order to achieve reasonable yields in the final condensation step and to assure formation of the difunctionalised products. Preparation of $\mathbf{H} \mathbf{L}^{1}-\mathbf{H L}^{\mathbf{4}}$ was carried out by the condensation of 6.0 equivalents of the corresponding substituted aniline with 1.0 equivalent of diketone $\mathbf{I}$ or dialdehyde $\mathbf{I I}$ in the presence of a catalytic amount (10 mol \%) of $p$-toluenesulfonic acid in toluene solution, using a DeanStark apparatus for the removal of water. After reacting for $72 \mathrm{~h}$, compounds $\mathbf{H} \mathbf{L}^{\mathbf{1}}-\mathbf{H} \mathbf{L}^{\mathbf{4}}$ are isolated as colourless solids by column chromatography in yields up to $85 \%$.

Crystals of $\mathbf{H L}^{\mathbf{1}}$ suitable for X-ray structural determination were grown from an ethanol solution layered with $n$-hexane, while crystals of $\mathbf{H L}^{4}$ were obtained from $\mathrm{CHCl}_{3}$. The molecular structures are shown in Figures 1 and 2 . In both cases, iminomethyl groups attached to the 3- and 5-positions of the heterocycle are roughly coplanar with the pyrazole ring, and both molecules adopt an anti-conformation with respect to the orientation of the two side arms attached to the pyrazole: while $\mathrm{N}(4)$ is located close to the pyrazole- $\mathrm{N}(2), \mathrm{N}(3)$ is directed towards the backside away from pyrazole-N(1). Hydrogen bonding between pairs of nitrogen atoms results in the formation of dimeric structures in the solid state, but H-bonding patterns are different for the two compounds. In $\mathbf{H} \mathbf{L}^{1}$ only the nitrogen atoms N(1) and N(2) of the pyrazole are involved in dimer formation, and the resulting dimer has crystallographically imposed inversion symmetry. In contrast, two crystallographically independent molecules constitute the dimeric structure of $\mathbf{H} \mathbf{L}^{4}$, in which hydrogen bonding occurs between pairs of pyrazole $[\mathrm{N}(2), \mathrm{N}(12)]$ and imine $[\mathrm{N}(4), \mathrm{N}(14)]$ nitrogen atoms. While the dimer motif observed for $\mathbf{H L}^{\mathbf{1}}$ is quite common for solid-state structures of pyrazole derivatives, ${ }^{[15]}$ the arrangement seen for $\mathbf{H} \mathbf{L}^{4}$ that involves other $\mathrm{H}$-bond acceptors in the same molecule is rare.

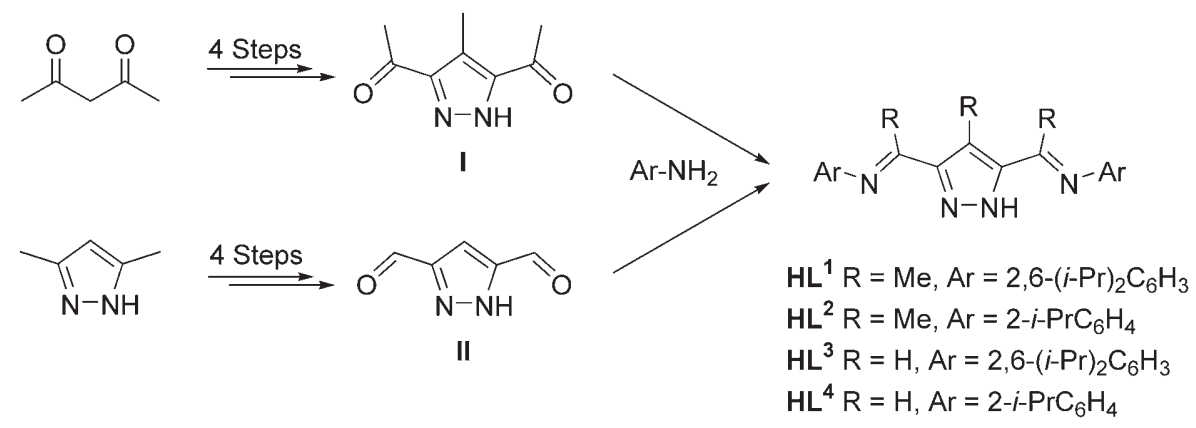

Scheme 2. Ligands used in this study. 


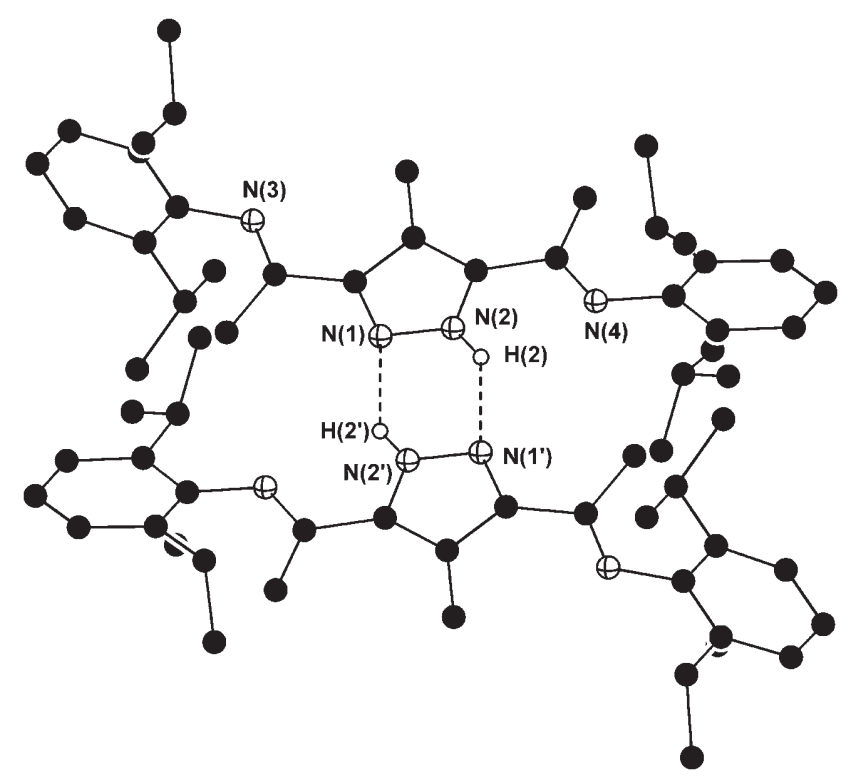

Figure 1. Hydrogen bond structure of $\mathbf{H L}^{\mathbf{1}}$. In the interest of clarity most hydrogen atoms have been omitted. Selected atom distances $(\AA)$ and angles $\left(^{\circ}\right)$ : $\mathrm{N}(2) \cdots \mathrm{N}\left(1^{\prime}\right) 2.898(3)$; $\mathrm{N}(2)-\mathrm{H}(2) \cdots \mathrm{N}\left(1^{\prime}\right) 144(2)$. Symmetry operation used to generate equivalent positions: (') $1-x, 1-y, 1-z$.

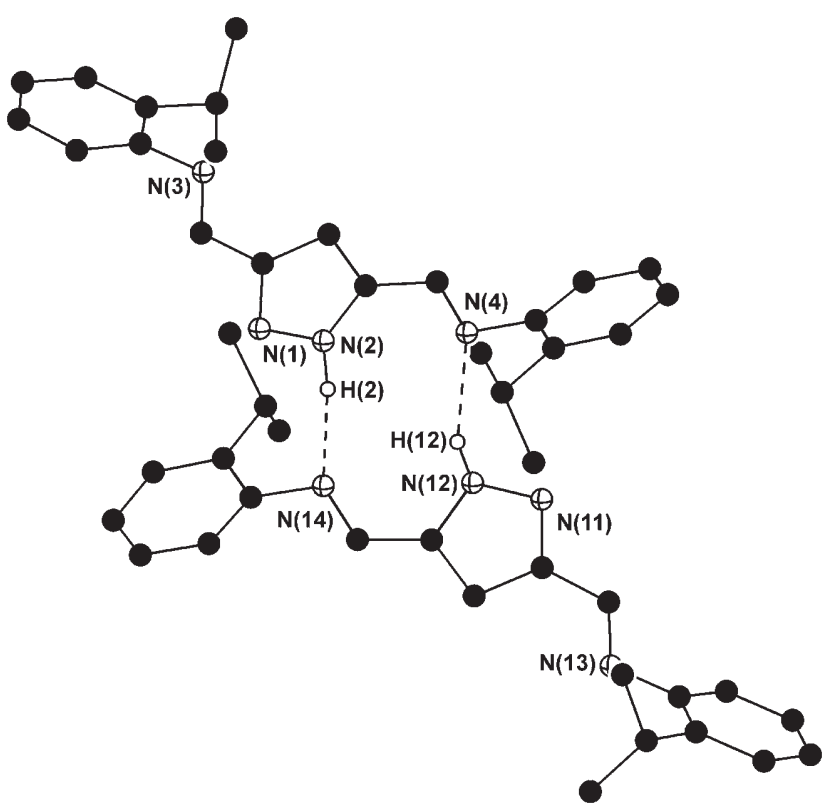

Figure 2. Hydrogen bond structure of $\mathbf{H L}^{4}$. In the interest of clarity most hydrogen atoms have been omitted. Selected atom distances $(\AA)$ and angles $\left(^{\circ}\right)$ : $\mathrm{N}(2) \cdots \mathrm{N}(14) 2.940(9)$, $\mathrm{N}(12) \cdots \mathrm{N}(4) \quad 2.947(9) ; \quad \mathrm{N}(2)-\mathrm{H}(2) \cdots \mathrm{N}(14) \quad 168(5)$, $\mathrm{N}(12)-\mathrm{H}(12) \cdots \mathrm{N}(4) 155$.

\section{Synthesis and Structural Characterisation of Complexes}

For the synthesis of dipalladium(II) and dinickel(II) complexes, the respective ligand was first deprotonated

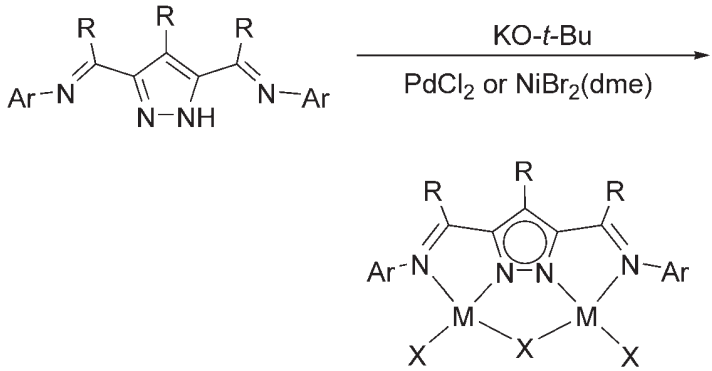

$$
\begin{array}{ll}
\text { 1a }\left(L^{1}, M=P d, X=C l\right) & \text { 1b }\left(L^{1}, M=N i, X=B r\right) \\
\text { 2a }\left(L^{2}, M=P d, X=C l\right) & \text { 2b }\left(L^{2}, M=N i, X=B r\right) \\
\text { 3a }\left(L^{3}, M=P d, X=C l\right) & \text { 3b }\left(L^{3}, M=N i, X=B r\right) \\
\text { 4a }\left(L^{4}, M=P d, X=C l\right) & \text { 4b }\left(L^{4}, M=N i, X=B r\right)
\end{array}
$$

Scheme 3. Syntheses of the complexes.

by means of a stoichiometric amount of KO-t-Bu in THF to generate the pyrazolate and then treated with 2 equivalents of either $\mathrm{PdCl}_{2}$ or $\mathrm{NiBr}_{2}(\mathrm{dme})$ (Scheme 3). After stirring at room temperature for $72 \mathrm{~h}$, the products were isolated as air-stable orange-red (Pd) or yellow (Ni) solids in moderate to good yield. They have been characterised by elemental analysis, mass spectrometry and IR spectroscopy, as well as by NMR spectroscopy for 1a and 3a. Complexes of $\left[\mathrm{L}^{2}\right]^{-}$and $\left[\mathrm{L}^{4}\right]^{-}$are poorly soluble in most common solvents, and all nickel complexes turned out to be paramagnetic in solution.

Upon complexation, the characteristic $\mathrm{C}=\mathrm{N}$ stretching frequency of the appended imine groups shifts from $1625-1642 \mathrm{~cm}^{-1}$ in the free ligands to 1530 $1561 \mathrm{~cm}^{-1}(\mathbf{1 a}-\mathbf{4 a})$ or $1555-1610 \mathrm{~cm}^{-1}(\mathbf{1 b}-\mathbf{4 b})$ in the complexes. For some of the nickel complexes, several strong bands in the latter range are observed, suggesting the presence of different isomers or species of different nuclearity. ESI mass spectra of acetonitrile solutions of the palladium complexes show prominent signals for the expected bimetallic compounds devoid of one of the $\mathrm{Cl}$ ligands, i.e., for the ions $\left[\mathrm{LPd}_{2} \mathrm{Cl}_{2}\right]^{+}$. In the case of 1a and 2a, however, peaks are also discernible for, inter alia, $\left[\mathrm{L}_{2} \mathrm{Pd}_{4} \mathrm{Cl}_{5}\right]^{+}$, again indicating the presence of some aggregation equilibria in solution that give rise to species of higher nuclearity. This is even more pronounced for the corresponding nickel complexes, where peaks not only for $\left[\mathrm{L}_{2} \mathrm{Ni}_{4} \mathrm{Br}_{5}\right]^{+}$, but also for hexametallic species $\left[\mathrm{L}_{3} \mathrm{Ni}_{6} \mathrm{Br}_{\mathrm{x}}\right]^{+}$are detected in some cases. The positive ion FAB mass spectrum of $\mathbf{3 b}$ is shown in Figure 3 as an example. While the most intense signal at $\mathrm{m} / \mathrm{z}=$ 1517 corresponds to the ion $\left[\mathrm{L}_{2}^{3} \mathrm{Ni}_{4} \mathrm{Br}_{5}\right]^{+}$, a prominent signal for $\left[\mathrm{L}_{3}^{3} \mathrm{Ni}_{6} \mathrm{Br}_{8}\right]^{+}$with the expected isotopic distribution pattern around $\mathrm{m} / z=2316$ suggests the existence of trimeric assemblies $\left[\mathrm{L}^{3} \mathrm{Ni}_{2} \mathrm{Br}_{3}\right]_{3}$ as a major species. This is confirmed by X-ray crystallography (see below).

Single crystals of 1a and 3a were grown from a dichloromethane solution layered with light petroleum. Molecular structures are shown in Figures 4 and 5, respectively. As anticipated, the compartmental ligand 


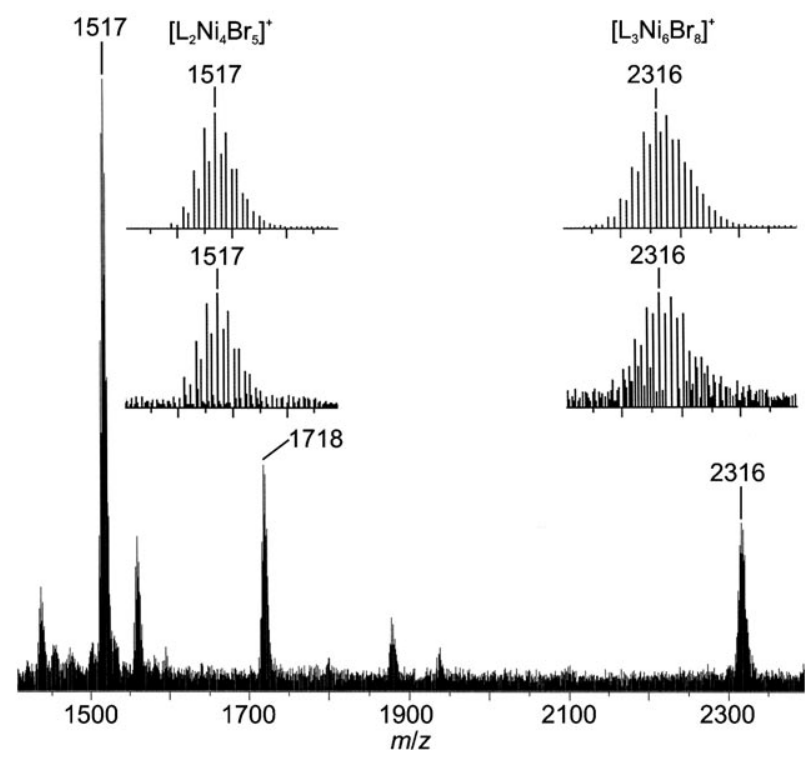

Figure 3. Part of the FAB mass spectrum of $\mathbf{3 b}$; the inset shows the experimental (lower) and theoretical (upper) isotopic distribution for tetranuclear $\left[\mathrm{L}_{2}^{3} \mathrm{Ni}_{4} \mathrm{Br}_{5}\right]^{+}$and hexanuclear $\left[\mathrm{L}_{3}^{3} \mathrm{Ni}_{6} \mathrm{Br}_{8}\right]^{+}$.

scaffolds form highly preorganised dinuclear palladium(II) complexes in which each metal is bound to one of the pyrazolate- $\mathrm{N}$ and to the adjacent imine-N. A bridging chloride as well as a terminal chloride at each palladium complete the bimetallic array. All metals ions are found in square planar environment [distance to the least squares planes of the four surrounding ligand atoms for Pd(1), 1a: 0.008(1) ̊̊, 3a: 0.012(1) $̊$; for Pd(2) 1a: $0.011(1) \AA$, 3a: $0.039(1) \AA]$ with their coordination planes lying roughly within the plane of the pyrazolate heterocycle. The appended bulky aryl groups are oriented perpendicular to this plane, and thus the isopropyl substituents block much of the outer space above and below the axial metal coordination sites. The only difference between 1a and 3a is the presence of the backbone methyl groups in the former case $(\mathrm{R}=$ Me versus $\mathrm{R}=\mathrm{H})$. Variations of the backbone substituents at the imine-C have been shown to greatly affect olefin polymerisation by mononuclear type $\mathbf{A} \alpha$-diimine catalysts. ${ }^{[16,17]}$ In the solid state structures investigated here, the presence of methyl groups $(\mathrm{R}=\mathrm{Me})$ in 1a has no significant influence on the bond distances and angles compared to $\mathbf{3 a}$. In both compounds the $\mathrm{Pd}-\mathrm{Cl}$ distances to the bridging chloride are about $0.1 \AA$ A longer than the distances to the terminal ones. A difference of the same magnitude can be found for the metal nitrogen bonds, where the distances to the imine-N are about $0.1 \AA$ longer than those to the pyrazolate- $\mathrm{N}$. The former values are quite similar to the $\mathrm{Pd}-\mathrm{N}_{\text {imine }}$ distances found in mononuclear diazabutadiene complexes of $\mathrm{PdCl}_{2}(\mathbf{I I I})^{[18]}$ or some related pyridylimine complexes IV ${ }^{[19,20]}$ In contrast, the bonds between $\mathrm{Pd}$ and the anionic pyrazolate in $\mathbf{1 a}$ and $\mathbf{3 a}$ $[1.909(5)-1.931(5) \AA]$ are significantly shorter than the $\mathrm{Pd}-\mathrm{N}_{\text {pyridine }}$ bonds in type $\mathbf{I V}$ systems (in the range 2.02-2.12 $\mathrm{A}$ ). However, $\mathrm{Pd}-\mathrm{Cl}$ distances trans to the pyrazolate-N or pyridine- $\mathrm{N}$ are all found in the narrow range $2.26-2.30 \AA$, suggesting a similar trans-influence of the two heterocyclic moieties. The $\mathrm{Pd} \cdot \mathrm{Pd}$ distances in $1 \mathbf{a}(3.76 \AA)$ and $\mathbf{3 a}(3.74 \AA)$ are longer than in a dinuclear diazabutadiene palladium complex with two $\mu$ chloro bridges $\left\{[(\mathrm{RNC}(\mathrm{Me}) \mathrm{C}(\mathrm{Me}) \mathrm{NR}) \mathrm{Pd}(\mu-\mathrm{Cl})]_{2}{ }^{2+}\right.$, $\left.\mathrm{R}=2,6-(i-\operatorname{Pr})_{2} \mathrm{C}_{6} \mathrm{H}_{3}, d(\mathrm{Pd} \cdots \mathrm{Pd})=3.41 \AA\right\},{ }^{[21]}$ but are typical for pyrazolate-based bimetallic systems. ${ }^{[22]}$<smiles>[R]C1=NN([Al])[R](Cl)(Cl)N([Al])C1[R]</smiles>

III

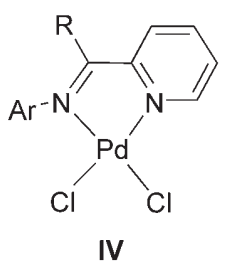

IV
The complex with $\mathrm{NiBr}_{2}$ and $\left[\mathrm{L}^{3}\right]^{-}, \mathbf{3 b}$ (Figure 6), differs substantially from the analogous square planar $\mathrm{Pd}$ complexes 1a or 3a. In 3b, three bimetallic $\left\{\mathrm{L}^{3} \mathrm{Ni}_{2} \mathrm{Br}_{3}\right\}$ building blocks have assembled to form a hexanuclear array, in accordance with the mass spectrometric findings discussed above. All metal ions are found in distorted octahedral coordination spheres. The cluster consists of two almost face-to-face arranged $\mathrm{Ni}_{3}(\mu-\mathrm{Br})_{3}$ rings (distance of the two ring centroids $4.11 \AA$, rotation angle of the two rings $8^{\circ}$ ) that are capped by two $\mu_{3}-\mathrm{Br}$ atoms and are held together by three pyrazolate ligands acting as outside clips. A unique $\mu_{6}$ - $\mathrm{Br}$ atom is nested inside the

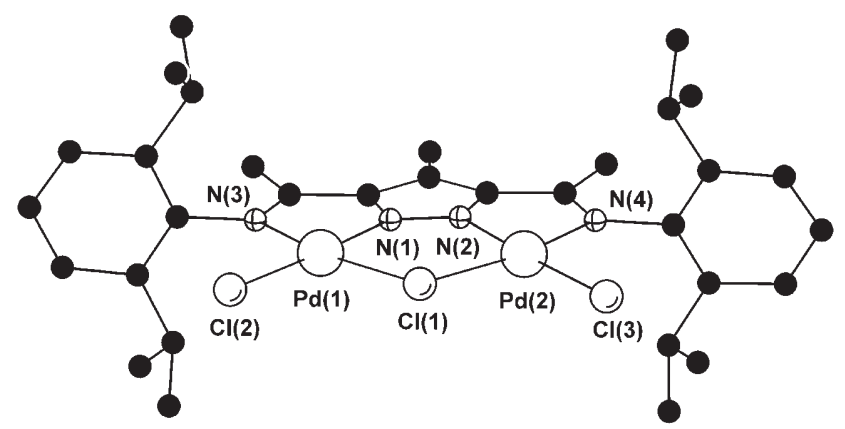

Figure 4. Molecular structure of 1a. In the interest of clarity all hydrogen atoms have been omitted. Selected atom distances $(\AA)$ and angles $\left(^{\circ}\right): \operatorname{Pd}(1)-\mathrm{N}(1)$ 1.909(5), $\operatorname{Pd}(1)-\mathrm{N}(3)$ 2.050(6), $\quad \mathrm{Pd}(1)-\mathrm{Cl}(1) \quad 2.396(2), \quad \mathrm{Pd}(1)-\mathrm{Cl}(2) \quad 2.276(2)$, $\mathrm{Pd}(2)-\mathrm{N}(2) \quad 1.930(6), \quad \mathrm{Pd}(2)-\mathrm{N}(4) \quad 2.051(6), \quad \mathrm{Pd}(2)-\mathrm{Cl}(1)$ 2.372(2), $\quad \operatorname{Pd}(2)-\mathrm{Cl}(3) \quad 2.289(2), \quad \operatorname{Pd}(1) \cdots \operatorname{Pd}(2) \quad 3.764(1)$; $\mathrm{N}(1)-\mathrm{Pd}(1)-\mathrm{N}(3) \quad 78.2(2) ; \quad \mathrm{N}(1)-\mathrm{Pd}(1)-\mathrm{Cl}(1) \quad 87.6(2)$, $\mathrm{N}(1)-\mathrm{Pd}(1)-\mathrm{Cl}(2) \quad 175.2(2), \quad \mathrm{N}(3)-\mathrm{Pd}(1)-\mathrm{Cl}(2) \quad 97.0(2)$, $\mathrm{Cl}(1)-\mathrm{Pd}(1)-\mathrm{N}(3) \quad 165.8(2), \quad \mathrm{Cl}(1)-\mathrm{Pd}(1)-\mathrm{Cl}(2) \quad 97.17(7)$, $\mathrm{Pd}(1)-\mathrm{Cl}(1)-\mathrm{Pd}(2) \quad$ 104.23(7), $\quad \mathrm{N}(2)-\mathrm{Pd}(2)-\mathrm{N}(4) \quad 77.6(2)$, $\mathrm{N}(2)-\mathrm{Pd}(2)-\mathrm{Cl}(1) \quad 88.1(2), \quad \mathrm{N}(2)-\mathrm{Pd}(2)-\mathrm{Cl}(3) \quad 175.9(2)$, $\mathrm{N}(4)-\mathrm{Pd}(2)-\mathrm{Cl}(1) \quad 165.6(2), \quad \mathrm{N}(4)-\mathrm{Pd}(2)-\mathrm{Cl}(3) \quad 98.4(2)$, $\mathrm{Cl}(1)-\mathrm{Pd}(2)-\mathrm{Cl}(3)$ 96.01(7). 


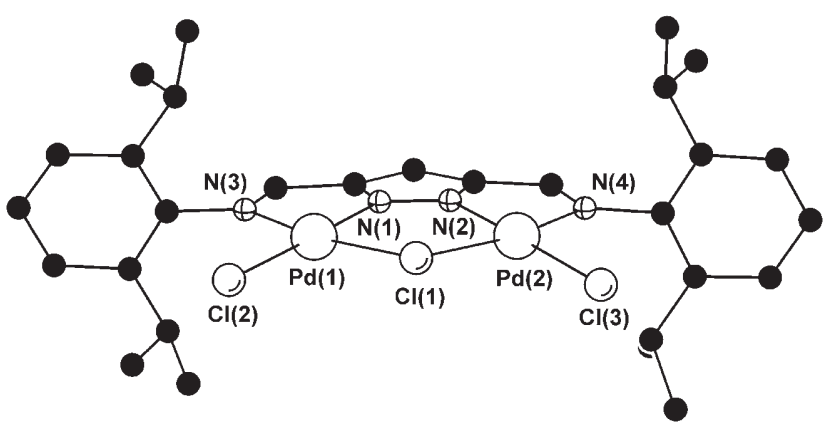

Figure 5. Molecular structure of 3a. In the interest of clarity all hydrogen atoms have been omitted. Selected atom distances $(\AA)$ and angles $\left(^{\circ}\right)$ : $\operatorname{Pd}(1)-\mathrm{N}(1)$ 1.931(5), $\operatorname{Pd}(1)-\mathrm{N}(3)$ 2.046(5), $\quad \mathrm{Pd}(1)-\mathrm{Cl}(1) \quad 2.385(2), \quad \mathrm{Pd}(1)-\mathrm{Cl}(2) \quad 2.291(2)$, $\mathrm{Pd}(2)-\mathrm{N}(2) \quad 1.926(5), \quad \mathrm{Pd}(2)-\mathrm{N}(4) \quad 2.048(5), \quad \mathrm{Pd}(2)-\mathrm{Cl}(1)$ 2.382(2), $\quad \mathrm{Pd}(2)-\mathrm{Cl}(3) \quad 2.271(2), \quad \operatorname{Pd}(1) \cdots \operatorname{Pd}(2) \quad 3.740(1)$; $\mathrm{N}(1)-\mathrm{Pd}(1)-\mathrm{N}(3) \quad 77.4(2), \quad \mathrm{N}(1)-\mathrm{Pd}(1)-\mathrm{Cl}(1) \quad 88.8(2)$, $\mathrm{N}(1)-\mathrm{Pd}(1)-\mathrm{Cl}(2) \quad 174.9(2), \quad \mathrm{N}(3)-\mathrm{Pd}(1)-\mathrm{Cl}(2) \quad 97.7(2)$, $\mathrm{Cl}(1)-\mathrm{Pd}(1)-\mathrm{N}(3) \quad 166.2(2), \quad \mathrm{Cl}(1)-\mathrm{Pd}(1)-\mathrm{Cl}(2) \quad 96.10(6)$, $\mathrm{Pd}(1)-\mathrm{Cl}(1)-\mathrm{Pd}(2) \quad 103.37(6), \quad \mathrm{N}(2)-\mathrm{Pd}(2)-\mathrm{N}(4) \quad 77.7(2)$, $\mathrm{N}(2)-\mathrm{Pd}(2)-\mathrm{Cl}(1) \quad 88.7(2), \quad \mathrm{N}(2)-\mathrm{Pd}(2)-\mathrm{Cl}(3) \quad 174.3(2)$, $\mathrm{N}(4)-\mathrm{Pd}(2)-\mathrm{Cl}(1) \quad 166.3(2), \quad \mathrm{N}(4)-\mathrm{Pd}(2)-\mathrm{Cl}(3) \quad 98.4(2)$, $\mathrm{Cl}(1)-\mathrm{Pd}(2)-\mathrm{Cl}(3)$ 95.24(6).

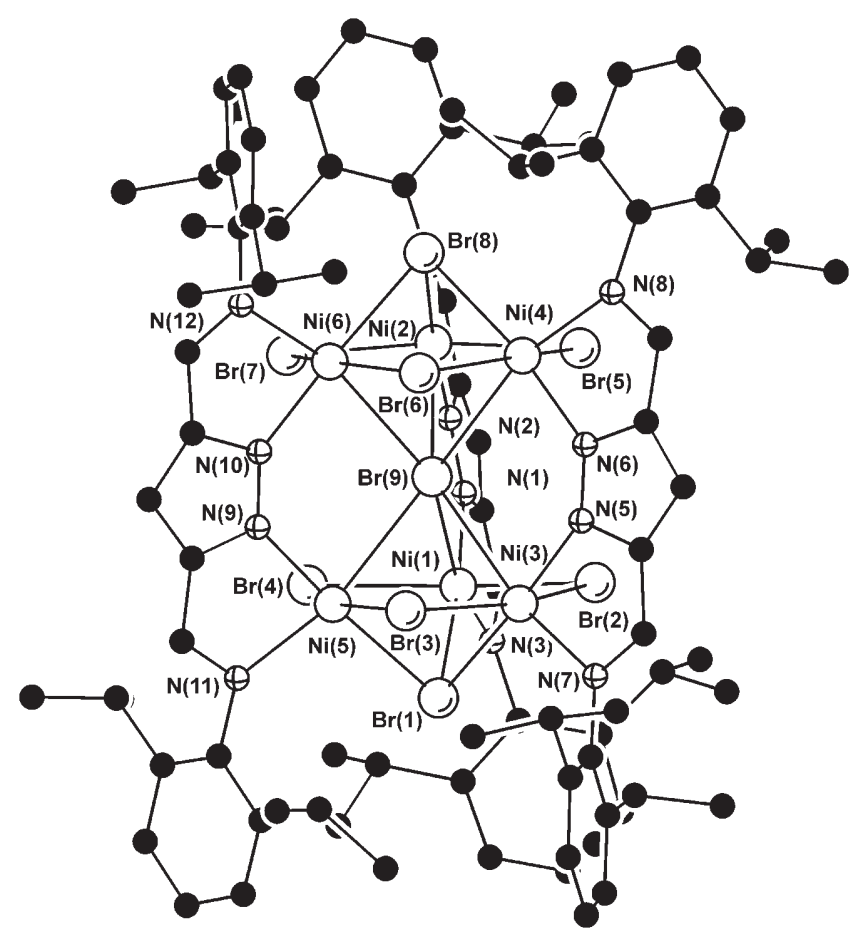

Figure 6. Molecular structure of $\mathbf{3 b}$. In the interest of clarity all hydrogen atoms have been omitted. Selected atom distances $(\AA)$ : $\mathrm{Ni}-(\mu-\mathrm{Br}) 2.506(1)-2.782(1), \mathrm{Ni}-\left(\mu_{3}-\mathrm{Br}\right) 2.540(1)-$ 2.593(1), Ni-Br(9) 2.782(1)-2.864(1), Ni- $\mathrm{N}_{\text {pyzazole }} 1.979(5)-$ $1.992(5), \mathrm{Ni}-\mathrm{N}_{\text {imine }} 2.098(5)-2.122(5), \mathrm{Ni} \cdot \cdots \mathrm{Ni}$ within the $\mathrm{Ni}_{3} \mathrm{Br}_{3}$ rings: $3.265(1)-3.309(1), \mathrm{Ni} \cdots \mathrm{Ni}$ bridged by pyrazolate: $4.191(1)-4.238(1)$. cage-like structure. The complex is iso-structural with the recently communicated structure of $\left[\mathrm{L}^{3} \mathrm{Ni}_{2} \mathrm{Cl}_{3}\right]_{3}$ except for the different halide. ${ }^{[8]}$ It should be noted that $\mu_{6}$-halide ligands bound to six metal atoms are very rare in discrete molecules, and for bromide only few structures of $\mathrm{Hg}$ compounds featuring a $\mu_{6}-\mathrm{Br}$ atom have been described in the literature to date. ${ }^{[23]}$

\section{Ethylene Polymerisation}

Palladium(II) and nickel(II) complexes 1a-4a and $\mathbf{1 b}-$ 4b were studied as catalyst precursors for ethylene polymerisation, with MAO as a cocatalyst. Results are summarised in Table 1. In all experiments the precatalyst complexes were dissolved in toluene and activated by MAO. Upon addition of MAO the colour of the solution changes from orange to dark red in the case of palladium(II) complexes 1a-4a and from yellow to red for nickel(II) complexes $\mathbf{1 b}-\mathbf{4 b}$. The red colour for the latter systems is indicative of the formation of square-planar low-spin nickel(II) species upon methylation and suggests that the hexanuclear aggregates observed in the solid state break down under these conditions, presumably giving rise to discrete type $\mathbf{B}$ dinuclear species.

Initial polymerisation runs were carried out without temperature control in order to obtain a rough estimate about the range of activities covered by the novel catalyst precursors. For all ligand systems the nickel complexes are significantly more active than the corresponding palladium complexes, and for both series of complexes the order of activity is $\mathbf{1}>\mathbf{2}>\mathbf{3}>\mathbf{4}$. Aryl groups with more sterically demanding substituents [2,6- $(i-$ $\operatorname{Pr})_{2} \mathrm{C}_{6} \mathrm{H}_{3}$ in $\mathbf{1}$ and $\mathbf{3}$ versus $2-i-\mathrm{PrC}_{6} \mathrm{H}_{4}$ in $\mathbf{2}$ and $\mathbf{4}$ ] and methyl groups at the diimine backbone (in $\mathbf{1}$ and $\mathbf{2}$ ) are obviously advantageous, as was previously reported for mononuclear diimine complexes. ${ }^{[2 a, 24]}$

The temperature inside the reactor was continuously monitored during these screening experiments, and the temperature pattern over the first $60 \mathrm{~min}$ is shown in Figure 7 for selected catalyst systems. It is apparent that polymerisation by the nickel catalysts generally is much more exothermic than for the corresponding palladium species. In particular, ethylene polymerisation by $\mathbf{1 b} /$ MAO is very exothermic under the reaction conditions studied. For all systems investigated, however, a maximum in the temperature curve is observed, suggesting a decreasing polymerisation rate due to thermal decomposition of the catalysts at higher temperatures. The catalyst decay mechanism is unknown at present, but temperature sensitivity and decomposition above $60^{\circ} \mathrm{C}$ have also been described as a general limitation for mononuclear type $\mathbf{A} \mathrm{Pd}(\mathrm{II})$ - $\alpha$-diimine or $\mathrm{Ni}(\mathrm{II})$ - $\alpha$-diimine catalysts. ${ }^{[24]}$ In addition, limiting monomer diffusion into more viscous polymer solutions might also play a role.

For subsequent experiments with the most active palladium complex (1a) as well as with all nickel complexes, 
Table 1. Ethylene polymerisation results. ${ }^{[a]}$

\begin{tabular}{rlllllr}
\hline Entry & $\begin{array}{l}\text { Precatalyst } \\
\text { complex }\end{array}$ & MAO/cat. & $\begin{array}{l}\text { Cat. amount } \\
{[\mu \mathrm{mol}]}\end{array}$ & $\begin{array}{l}\text { Temp. } \\
\text { control }\end{array}$ & $\begin{array}{l}\text { Yield PE } \\
{[\mathrm{g}]}\end{array}$ & $\begin{array}{l}\text { Activity } \\
{\left[\mathrm{kg}_{\mathrm{PE}} \cdot \mathrm{mol}_{\mathrm{cat}}{ }^{-1} \cdot \mathrm{h}^{-1} \cdot \mathrm{bar}^{-1}\right]}\end{array}$ \\
\hline 1 & $\mathbf{1 a}$ & 1000 & 5.0 & No & 0.59 & 47 \\
2 & $\mathbf{1 a}$ & 1000 & 5.0 & $18{ }^{\circ} \mathrm{C}$ & 1.83 & 146 \\
3 & $\mathbf{2 a}$ & 1000 & 5.0 & No & 0.47 & 37 \\
4 & $\mathbf{3 a}$ & 1000 & 5.0 & No & 0.42 & 33 \\
5 & $\mathbf{4 a}$ & 1000 & 5.0 & No & 0.24 & 19 \\
6 & $\mathbf{1 b}$ & 1000 & 5.0 & No & 5.43 & 434 \\
7 & $\mathbf{1 b}$ & 500 & 2.5 & $18^{\circ} \mathrm{C}$ & 2.02 & 323 \\
8 & $\mathbf{1 b}$ & 1000 & 2.5 & $18{ }^{\circ} \mathrm{C}$ & 3.48 & 557 \\
9 & $\mathbf{1 b}$ & 2000 & 2.5 & $18^{\circ} \mathrm{C}$ & 3.54 & 566 \\
10 & $\mathbf{1 b}$ & 3000 & 2.5 & $18^{\circ} \mathrm{C}$ & 3.87 & 619 \\
11 & $\mathbf{2 b}$ & 1000 & 5.0 & No & 3.11 & 249 \\
12 & $\mathbf{2 b}$ & 1000 & 2.5 & $18^{\circ} \mathrm{C}$ & 2.51 & 402 \\
13 & $\mathbf{3 b}$ & 1000 & 5.0 & No & 1.40 & 112 \\
14 & $\mathbf{3 b}$ & 1000 & 2.5 & $18^{\circ} \mathrm{C}$ & 1.47 & 235 \\
15 & $\mathbf{4 b}$ & 1000 & 5.0 & No & 0.89 & 71 \\
\hline
\end{tabular}

[a] Experimental conditions: 200-mL stirred glass reactor, $80 \mathrm{ml}$ toluene, $p\left(\mathrm{C}_{2} \mathrm{H}_{4}\right)=2.5$ bar, reaction time $1 \mathrm{~h}$.

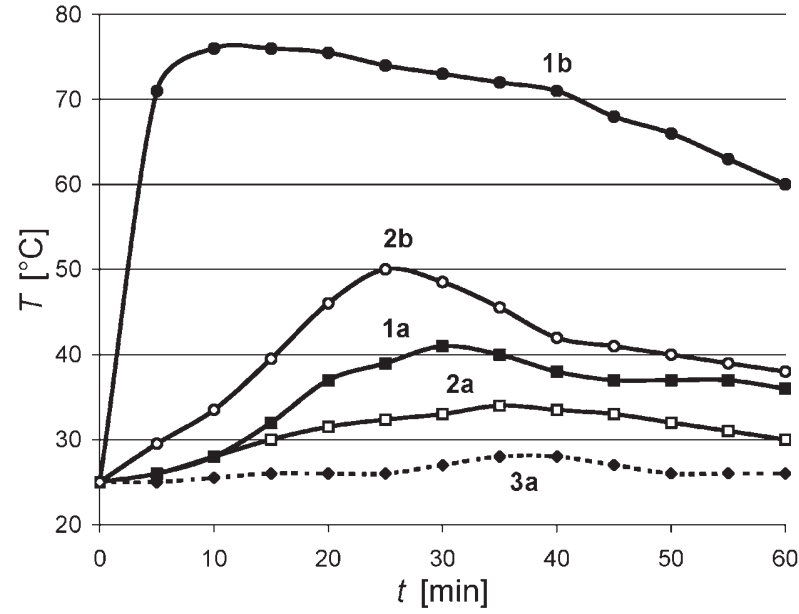

Figure 7. Temperature variation during ethylene polymerisation in the absence of temperature control [conditions: $p\left(\mathrm{C}_{2} \mathrm{H}_{4}\right)=2.5$ bar, $\mathrm{MAO} /$ precursor complex $\mathbf{1}$ to $\mathbf{4}=1000$, $80 \mathrm{~mL}$ toluene, $5 \mu \mathrm{mol}$ catalyst precursor].

the temperature inside the reactor was controlled by an external thermostat bath and was held roughly constant at $18^{\circ} \mathrm{C}$ (Table 1$)$. Overall structure/activity correlations remain valid under these conditions, i.e., methyl substituents at the ligand backbone as well as bulky groups at the aryl rings increase the polymerisation rate. Variation of the cocatalyst/catalyst ratio (MAO/ cat) does have an effect on activity, although this effect levels of at ratios $>1000$ (entries 7-10, Table 1). In order to evaluate the catalyst stability over time, in a series of experiments with the most active complex $\mathbf{1 b}$ the reaction mixtures were quenched after different time intervals and polymer yields were determined. Figure 8 reveals that activity remains high and fairly constant

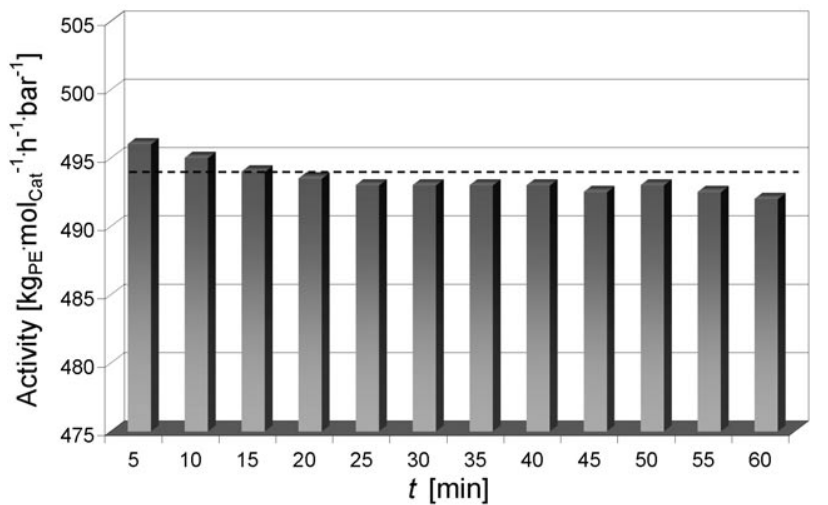

Figure 8. Long-time polymerisation activity for $\left[\mathrm{L}^{1} \mathrm{Ni}_{2} \mathrm{Br}_{3}\right]_{\mathrm{x}}$ (1b) [conditions: $p\left(\mathrm{C}_{2} \mathrm{H}_{4}\right)=2.5 \mathrm{bar}, 5 \mu \mathrm{mol} \mathbf{1 b}, \mathrm{MAO} / \mathrm{cat} .=$ $1000,80 \mathrm{~mL}$ toluene, temperature controlled at $\left.18^{\circ} \mathrm{C}\right]$.

over at least $1 \mathrm{~h}$, confirming good stability of the active species under thermostat conditions. The observed activities in this series of experiments also confirm a good reproducibility of the catalytic polymerisations.

Comparison with literature data reveals that ethylene polymerisation activity of the most active system $\mathbf{1 b}$ / MAO is of the same order of magnitude as for the related mononuclear catalyst $\mathbf{V}$ [which was reported to produce $420 \mathrm{~kg}_{\mathrm{PE}} /\left(\mathrm{mol}_{\mathrm{Ni}} \cdot \mathrm{h}\right)$ at $35^{\circ} \mathrm{C}$ and 1 bar ethylene]. ${ }^{[24]}$

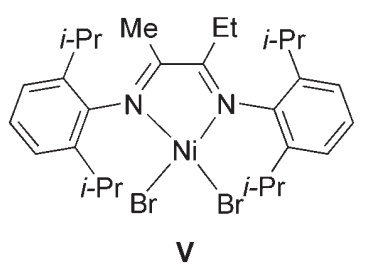


Table 2. Polymer properties.

\begin{tabular}{lcllrr}
\hline $\begin{array}{l}\text { Precatalyst } \\
\text { complex }\end{array}$ & Entry in Table 1 & $M_{\mathrm{n}}[\mathrm{g} / \mathrm{mol}]$ & $\begin{array}{l}\text { Polydispersity } \\
M_{\mathrm{w}} / M_{\mathrm{n}}\end{array}$ & $T_{\mathrm{m}}\left[{ }^{\circ} \mathrm{C}\right]$ & $\begin{array}{r}\text { Branches per } \\
1000 \mathrm{C} \text { atoms }\end{array}$ \\
\hline $\mathbf{1 b}$ & & $3.3 \times 10^{5}$ & 2.4 & 74 & 56 \\
$\mathbf{3 b}$ & 8 & $3.7 \times 10^{5}$ & 2.7 & 76 & 51 \\
$\mathbf{V}$ & 14 & $1.7 \times 10^{5}$ & 1.6 & -2 & 101 \\
$\mathbf{V}^{[\mathrm{b}]}$ & - & $7.7 \times 10^{5}$ & 1.7 & 96 & 28 \\
\hline
\end{tabular}

[a] Determined by ${ }^{1} \mathrm{H}$ NMR spectroscopy.

${ }^{[b, c]}$ Results from ref. ${ }^{[24]}$ Polymers prepared at $35^{\circ} \mathrm{C}, \mathrm{MAO} / \mathrm{cat}=1000$ to 3000,100 to $200 \mathrm{~mL}$ toluene, 1 to $2 \mu \mathrm{mol} \mathrm{Ni}$, ethylene pressure for [b]: $1 \mathrm{~atm},[\mathrm{c}]: 15 \mathrm{~atm}$.

Polymer properties were studied for two selected samples, prepared with nickel(II) catalysts $\mathbf{1 b}$ and $\mathbf{3 b}$ that carry the same bulky 2,6-diisopropylphenyl imine substituents but differ in the backbone substitution. High temperature GPC shows the polymers to be of high molecular weight (Table 2). Number average molecular weights of several $10^{5} \mathrm{~g} \cdot \mathrm{mol}^{-1}$ were determined versus linear polyethylene standards. Molecular weight distributions and the monomodality of the GPC traces indicate a well-behaved single site-type nature of the active species. A total branching of 50 to 60 branches per 1000 $\mathrm{C}$ atoms results in a much decreased melting point and crystallinity compared to linear polyethylene. The backbone substitution pattern $(\mathrm{Me}$ or $\mathrm{H})$ of the catalyst appears to have no strong impact on the polymer microstructure. Overall, the polymer properties are rather similar to those obtained under similar conditions with the mononuclear diimine complex $\mathbf{V}$ (Table 2, properties of polymers prepared with $\mathbf{V}$ at 1 atm and at $15 \mathrm{~atm}$ ethylene pressure are given for comparison with the polymers prepared in this work at $2.5 \mathrm{~atm}$ ). Note that branching decreases and correspondingly the melt temperature increases at higher ethylene pressure during polymerisation.

\section{Conclusions}

A set of pyrazolate-based ligands with appended arylimino side arms has been prepared that provide two adjacent bidentate metal ion binding compartments similar to the classical $\alpha$-diimine type. In the case of bulky ortho aryl groups, these ligands form highly preorganised dipalladium(II) complexes with square-planar metal ions. Nickel (II) complexes tend to form oligomeric species both in solution and in the solid state. Upon activation of the new complexes with MAO and exposure to ethylene, polyethylene is formed. The following conclusions regarding ethylene polymerisation can be drawn from this work:

(i) The dinuclear complexes can be viewed as bimetallic versions of Brookhart-type $\alpha$-diimine olefin polymerisation precatalysts, where the two adjacent metal ions are suitably positioned for cooperative action. (ii) Dinuclear nickel complexes show high activity and are significantly more active than the corresponding palladium systems, in close analogy to observations for the mononuclear catalysts.

(iii) Increased steric bulk of the aryl ortho substituents and the presence of substituents at the ligand backbone lead to higher activity.

(iv) Polymer microstructures are rather similar to those obtained with related mononuclear $\alpha$-diimine complexes under similar conditions, even though dissociation into monomeric complexes is prevented by the dinucleating ligand scaffold for the new bimetallic pyrazolate/imine systems. With bulky 2,6-diisopropylphenyl-substituted systems, $M_{\mathrm{n}}$ values are in the order of $3.5 \times 10^{5} \mathrm{~g} / \mathrm{mol}$, but no effect of different backbone substituents ( $\mathrm{H}$ versus $\mathrm{Me}$ ) is discernible. Quite extensive branching leads to polymers with relatively low crystallinity, while molecular weight distributions indicate a well-behaved single-site type nature of the active species.

Future work will focus on beneficial modifications of the ligand scaffold, on polymerisation of monomers other than ethylene, and on mechanistic aspects of the polymerisation process. It remains to be elucidated whether (and how) the proximate metal ions in the new complexes work in concert during substrate turnover.

\section{Experimental Section}

\section{General}

Compounds $\mathbf{I}{ }^{[13]} \mathbf{I I}^{[14]}$ and $\mathbf{H} \mathbf{L}^{3[7]}$ were synthesised according to published procedures. In order to improve the conversion yield in the last step of the synthesis of $\mathbf{I I}$, a mixture of water and ethanol $(1: 4)$ instead of pure water was used as the solvent. Characterisation data for $\mathbf{H L}^{\mathbf{1}}, \mathbf{H L}^{\mathbf{2}}, \mathbf{H L}^{\mathbf{4}}, \mathbf{1 a}-\mathbf{4 a}$, and $\mathbf{1 b}-\mathbf{4 b}$ can be found in the Supporting Information. Solvents were dried under reflux $\left(\mathrm{CaH}_{2}\right.$ for dichloromethane; $\mathrm{Na} / \mathrm{K}$-alloy for toluene, diethyl ether, THF and light petroleum) and distilled prior to use. All reactions were carried out under nitrogen atmosphere using standard Schlenk techniques. Anilines were purchased from Aldrich and purified by distillation prior to use. $\mathrm{PdCl}_{2}$ and $\mathrm{NiBr}_{2}(\mathrm{dme})$ were purchased from Aldrich and used as received. Ethylene (99.9\%) was purchased from Messer 
Group GmbH. Methyl aluminoxane (MAO) was obtained from Albemarle ${ }^{\circledR}$ Europe SPRL as a $30 \mathrm{wt} \%$ solution in toluene.

\section{3,5-Bis(2,6-diisopropylphenyliminoacetyl)-1H-4- methylpyrazole (HL ${ }^{1}$ )}

A solution of diketone $\mathbf{I}(1.66 \mathrm{~g}, 10 \mathrm{mmol})$ and 2,6-diisopropylaniline $(10.62 \mathrm{~g}, 60 \mathrm{mmol})$ in toluene $(150 \mathrm{~mL})$ with a catalytic amount of $p$-toluenesulfonic acid $(0.20 \mathrm{~g})$ was heated to reflux for $72 \mathrm{~h}$ using a Dean-Stark apparatus for the removal of water. After the solvent had been removed under reduced pressure, the remaining white powder was purified by column chromatography (light petroleum: $\mathrm{Et}_{2} \mathrm{O}=9: 1$ ), dried under vacuum and finally crystallised from ethanol. Single crystals were obtained from an ethanol solution layered with $n$-hexane. Yield: $3.70 \mathrm{~g}(76 \%)$.

\section{3,5-Bis(2-isopropylphenyliminoacetyl)-1H-4- methylpyrazole $\left(\mathbf{H L}^{2}\right)$}

A solution of diketone $\mathbf{I}(1.66 \mathrm{~g}, 10 \mathrm{mmol})$ and 2-isopropylaniline $(6.42 \mathrm{~g}, 60 \mathrm{mmol})$ in toluene $(150 \mathrm{~mL})$ with a catalytic amount of $p$-toluenesulfonic acid $(0.20 \mathrm{~g})$ was heated to reflux using a Dean-Stark apparatus for the removal of water for $72 \mathrm{~h}$. After the solvent had been removed under reduced pressure, the remaining white powder was purified by column chromatography (light petroleum: $\mathrm{Et}_{2} \mathrm{O}=9: 1$ ) and dried under vacuum. Yield: $3.27 \mathrm{~g}(82 \%)$.

\section{3,5-Bis(2-isopropylphenyliminomethyl)-1H-pyrazole $\left(\mathbf{H L}^{4}\right)$}

A solution of dialdehyde II $(1.24 \mathrm{~g}, 10 \mathrm{mmol})$ and 2-isopropylaniline $(6.42 \mathrm{~g}, 60 \mathrm{mmol})$ in toluene $(150 \mathrm{~mL})$ with a catalytic amount of $p$-toluenesulfonic acid $(0.20 \mathrm{~g})$ was heated to reflux using a Dean-Stark apparatus for the removal of water for $72 \mathrm{~h}$. After the solvent had been removed under reduced pressure, the remaining white powder was purified by column chromatography (light petroleum: $\mathrm{Et}_{2} \mathrm{O}=9: 1$ ), dried under vacuum and finally crystallised from ethanol. Single crystals were obtained from a $\mathrm{CHCl}_{3}$ solution. Yield: $3.29 \mathrm{~g} \mathrm{(92 \% ).}$

\section{[ $\left.\mathbf{L}^{\mathbf{1}} \mathbf{P d}_{\mathbf{2}} \mathbf{C l}_{3}\right]$ (1a)}

To a stirred solution of $\mathbf{H L}^{\mathbf{1}}(242 \mathrm{mg}, 0.5 \mathrm{mmol})$ and KO- $t$-Bu $(56 \mathrm{mg}, 0.5 \mathrm{mmol})$ in THF $(50 \mathrm{~mL}), \mathrm{PdCl}_{2} \quad(177.4 \mathrm{mg}$, $1.0 \mathrm{mmol}$ ) was added. The suspension was stirred for $72 \mathrm{~h}$ at room temperature and then evaporated to dryness. The resulting orange powder was taken up in $\mathrm{CH}_{2} \mathrm{Cl}_{2}(40 \mathrm{~mL})$, filtered and the solution layered with light petroleum to gradually afford single crystals of 1a. Yield: $324 \mathrm{mg}(80 \%)$.

\section{[ $\left.\mathbf{L}^{2} \mathbf{P d}_{2} \mathbf{C l}_{3}\right]$ (2a)}

To a stirred solution of $\mathbf{H L}^{2}$ (200 mg, $0.5 \mathrm{mmol}$ ) and KO- $t$-Bu $(56 \mathrm{mg}, 0.5 \mathrm{mmol})$ in THF $(50 \mathrm{~mL}), \mathrm{PdCl}_{2} \quad(177.4 \mathrm{mg}$, $1.0 \mathrm{mmol}$ ) was added. The suspension was stirred for $72 \mathrm{~h}$ at room temperature and then evaporated to dryness. The resulting red powder was taken up in $\mathrm{CH}_{2} \mathrm{Cl}_{2}(40 \mathrm{~mL})$ and filtered. All volatile material was then evaporated under reduced pressure to give 2a. Yield: $280 \mathrm{mg}$ (78\%).

\section{$\left[\mathbf{L}^{3} \mathbf{P d}_{2} \mathbf{C l}_{3}\right]$ (3a)}

To a stirred solution of $\mathbf{H L}^{3}(221 \mathrm{mg}, 0.5 \mathrm{mmol})$ and KO- $t$-Bu $(56 \mathrm{mg}, \quad 0.5 \mathrm{mmol})$ in THF $(50 \mathrm{~mL}), \mathrm{PdCl}_{2} \quad(177.4 \mathrm{mg}$, $1.0 \mathrm{mmol}$ ) was added. This suspension was stirred for $72 \mathrm{~h}$ at room temperature and then evaporated to dryness. The resulting orange powder was taken up in $\mathrm{CH}_{2} \mathrm{Cl}_{2}(40 \mathrm{~mL})$, filtered and the solution layered with light petroleum to gradually afford single crystals of 3a. Yield: $334 \mathrm{mg}$ (88\%).

\section{$\left[\mathbf{L}^{4} \mathbf{P d}_{2} \mathbf{C l}_{3}\right]$ (4a)}

To a stirred solution of $\mathbf{H L}^{4}(179 \mathrm{mg}, 0.5 \mathrm{mmol})$ and KO- $t$-Bu $(56 \mathrm{mg}, \quad 0.5 \mathrm{mmol})$ in THF $(50 \mathrm{~mL}), \mathrm{PdCl}_{2}(177.4 \mathrm{mg}$, $1.0 \mathrm{mmol}$ ) was added. This suspension was stirred for $72 \mathrm{~h}$ at room temperature and then evaporated to dryness. The resulting orange powder was taken up in $\mathrm{CH}_{2} \mathrm{Cl}_{2}(40 \mathrm{~mL})$ and filtered. All volatile material was then evaporated under reduced pressure to give 4a. Yield: $276 \mathrm{mg}(82 \%)$.

\section{$\left[\mathbf{L}^{1} \mathbf{N i}_{2} \mathbf{B r}_{3}\right]_{\mathbf{x}}(\mathbf{1 b})$}

To a stirred solution of $\mathbf{H L}^{\mathbf{1}}(242 \mathrm{mg}, 0.5 \mathrm{mmol})$ and KO- $t$-Bu $(56 \mathrm{mg}, 0.5 \mathrm{mmol})$ in THF $(50 \mathrm{~mL}), \mathrm{NiBr}_{2}(\mathrm{dme})(353 \mathrm{mg}$, $1.0 \mathrm{mmol}$ ) was added. This suspension was stirred for $72 \mathrm{~h}$ at room temperature and then evaporated to dryness. The resulting yellow powder was taken up in $40 \mathrm{~mL}$ of $\mathrm{CH}_{2} \mathrm{Cl}_{2}$ and filtered. All volatile material was then evaporated under reduced pressure to give 1b. Yield: $309 \mathrm{mg}$ (74\%).

\section{$\left[\mathbf{L}^{2} \mathbf{N i}_{2} \mathbf{B r}_{3}\right]_{\mathbf{x}}(\mathbf{2 b})$}

To a stirred solution of $\mathbf{H L}^{2}(200 \mathrm{mg}, 0.5 \mathrm{mmol})$ and KO- $t$-Bu $(56 \mathrm{mg}, 0.5 \mathrm{mmol})$ in THF $(50 \mathrm{~mL}), \mathrm{NiBr}_{2}(\mathrm{dme})(353 \mathrm{mg}$, $1.0 \mathrm{mmol}$ ) was added. This suspension was stirred for $72 \mathrm{~h}$ at room temperature and then evaporated to dryness. The resulting orange powder was taken up in $\mathrm{CH}_{2} \mathrm{Cl}_{2}(40 \mathrm{~mL})$ and filtered. All volatile material was then evaporated under reduced pressure to give $\mathbf{2 b}$. Yield: $267 \mathrm{mg}$ (77\%).

\section{$\left[\mathbf{L}^{3} \mathbf{N i}_{2} \mathbf{B r}_{3}\right]_{\mathbf{x}}(\mathbf{3 b})$}

To a stirred solution of $\mathbf{H L}^{3}$ (221 mg, $0.5 \mathrm{mmol}$ ) and KO- $t$-Bu $(56 \mathrm{mg}, 0.5 \mathrm{mmol})$ in THF $(50 \mathrm{~mL}), \mathrm{NiBr}_{2}(\mathrm{dme})(353 \mathrm{mg}$, $1.0 \mathrm{mmol}$ ) was added. This suspension was stirred for $72 \mathrm{~h}$ at room temperature and then evaporated to dryness. The resulting yellow powder was taken up in $\mathrm{CH}_{2} \mathrm{Cl}_{2}(40 \mathrm{~mL})$ and filtered. Single crystals were obtained by layering this solution with light petroleum. Yield: $223 \mathrm{mg}$ (68\%). 


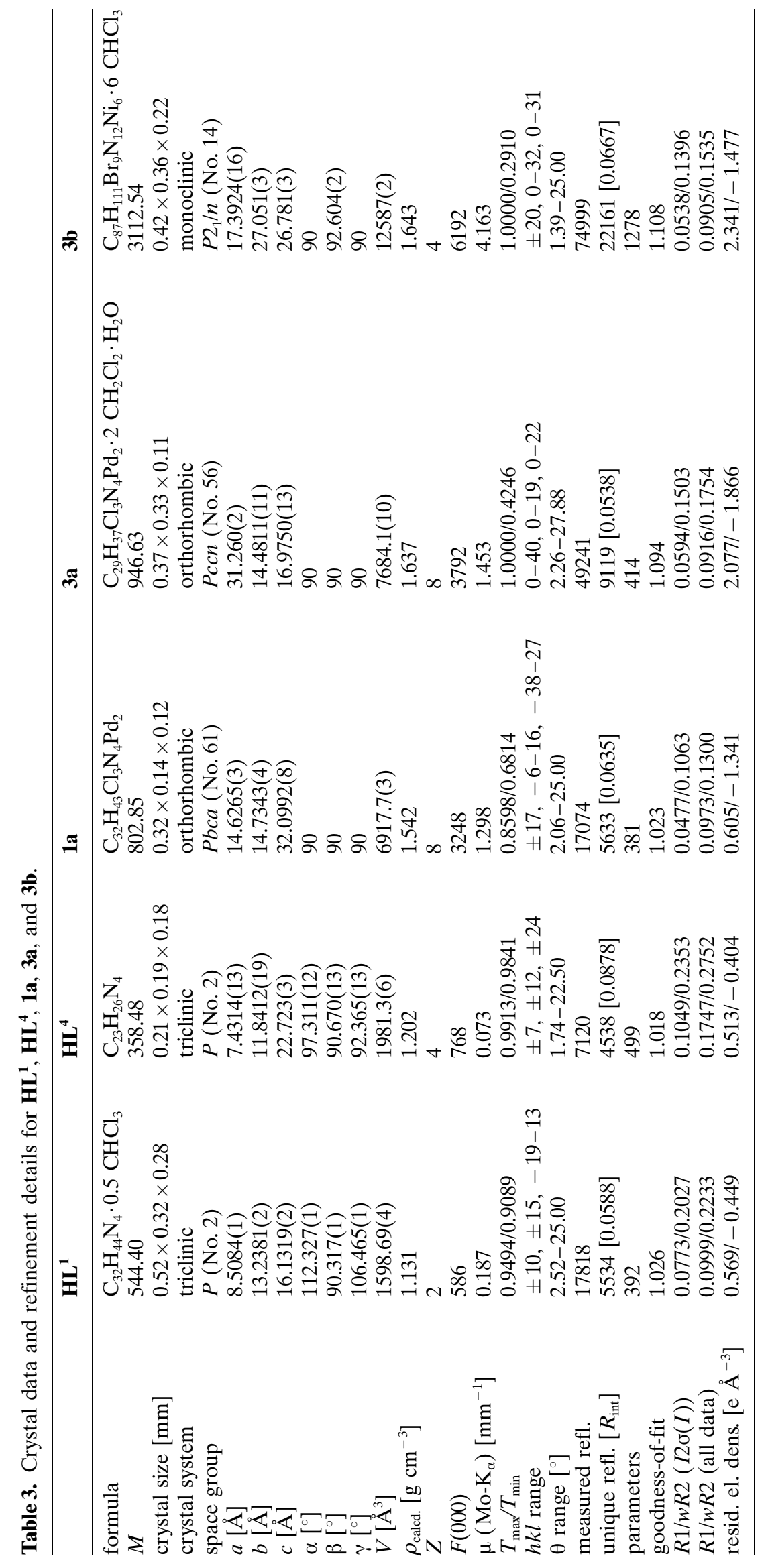




\section{$\left[\mathbf{L}^{4} \mathbf{N i}_{2} \mathbf{B r}_{3}\right]_{\mathbf{x}}(\mathbf{4 b})$}

To a stirred solution of $\mathbf{H L}^{4}(179 \mathrm{mg}, 0.5 \mathrm{mmol})$ and KO- $t$-Bu $(56 \mathrm{mg}, 0.5 \mathrm{mmol})$ in THF $(50 \mathrm{~mL}), \mathrm{NiBr}_{2}(\mathrm{dme})(353 \mathrm{mg}$, $1.0 \mathrm{mmol}$ ) was added. This suspension was stirred for $72 \mathrm{~h}$ at room temperature and then evaporated to dryness. The resulting orange powder was taken up in $\mathrm{CH}_{2} \mathrm{Cl}_{2}(40 \mathrm{~mL})$ and filtered. All volatile material was then evaporated under reduced pressure. Yield: $287 \mathrm{mg}(81 \%)$. According to the elemental analysis, the compound may still contain one equivalent of THF per dinickel unit.

\section{General Procedure for Polymerisation}

In a 200-mL stirred glass reactor flushed with nitrogen the appropriate amount of catalyst was added as a solution in toluene $(80 \mathrm{~mL}$ ). After the addition of MAO (for MAO/catalyst ratios see Table 1) the nitrogen atmosphere was replaced by ethylene. The pressure inside the reactor was kept at 2.5 bar for 1 hour. Finally the reaction was quenched with methanol $(50 \mathrm{~mL})$, and the obtained polyethylene was separated by filtration, washed with methanol and dried under vacuum to constant weight.

\section{Polymer Characterisation}

Differential scanning calorimetry was performed on a Netzsch DSC $204 \mathrm{~F} 1$ instrument at a heating and cooling rate of $10 \mathrm{~K} /$ min. DSC data reported are second heats. High temperature NMR spectra were performed in 1,1,2,2-tetrachloroethane- $d_{2}$ at $130{ }^{\circ} \mathrm{C}$ on a Varian Inova 400 spectrometer. Molecular weights were determined with a PL GPC-220 instrument equipped with mixed $\mathrm{B}$ columns in trichlorobenzene at $160^{\circ} \mathrm{C} v$ s. linear polyethylene standards.

\section{X-Ray Crystallographic Studies}

X-ray data were collected on a four circle CCD $\left(\mathbf{1 a}, \mathbf{H L}^{\mathbf{1}}\right)$, a STOE IPDS II $\left(\mathbf{H L}^{4}\right)$, and a Bruker AXS CCD diffractometer (3a, 3b) (graphite monochromated Mo-K $\alpha$ radiation, $\lambda=$ $0.71073 \AA)$ at $-140^{\circ} \mathrm{C}\left(\mathbf{1 a}, \mathbf{H L}^{\mathbf{1}}, \mathbf{H L}^{\mathbf{4}}\right)$ and $-83^{\circ} \mathrm{C}(\mathbf{3 a}, \mathbf{3 b})(\mathrm{Ta}-$ ble 3$)$. The structures were solved by direct methods and refined on $F^{2}$ using all reflections with SHELX-97. ${ }^{[25]}$ The nonhydrogen atoms were refined anisotropically. Hydrogen atoms which were not involved in hydrogen bonding were placed in calculated positions and assigned to an isotropic displacement parameter of $0.08 \AA^{2}\left(\mathbf{1 a}, \mathbf{H L}^{\mathbf{1}}, \mathbf{H L}^{\mathbf{4}}\right)$, or included using the riding model $(\mathbf{3 a}, \mathbf{3 b})$. The positional and isotropic thermal parameters of the nitrogen-bonded hydrogen atom $\mathrm{H}(2)$ in $\mathbf{H L}^{\mathbf{1}}$ and $\mathbf{H L}^{4}$ were refined without constraints. SADABS was used to perform area-detector scaling and absorption corrections for 1a, 3a, 3b, and $\mathbf{H L}^{\mathbf{1}}{ }^{\left[{ }^{[26]}\right.}$ Face-indexed absorption corrections were performed numerically with the program X-RED for $\mathbf{H L}^{4}{ }^{[27]}$ Disordered solvent molecules were found in $\mathbf{3 b}$ $\left(\mathrm{CHCl}_{3}\right)$ and were refined in the usual manner, as well as the disordered solvent molecules on special positions in 1a $\left(\mathrm{CHCl}_{3}\right)$ and $\mathbf{3 a}\left(\mathrm{CH}_{2} \mathrm{Cl}_{2}, \mathrm{H}_{2} \mathrm{O}\right)$. For some solvent molecules in $\mathbf{3 b}$ no satisfactory model for the disorder could be found, and for further refinement the contribution of the missing solvent molecules ( $980 \AA^{3}$, total electron count 210 ) was subtract- ed from the reflection data by the SQUEEZE ${ }^{[28]}$ routine of the PLATON ${ }^{[2]}$ program. Additionally the methyl groups [C(28), $\mathrm{C}(29)$ ] of one isopropyl side arm in $\mathbf{H L}^{\mathbf{1}}$ are disordered about two positions. The respective occupancy factors were refined to $0.52(3) / 0.48(3)$.

CCDC-256780 (HL $\left.{ }^{\mathbf{1}}\right)$, CCDC-256781 (HL $\left.{ }^{4}\right)$, CCDC-256782 (1a), CCDC-256783 (3a), and CCDC-256784 (3b) contain the supplementary crystallographic data for this paper. These data can be obtained free of charge at www.ccdc.cam.ac.uk/ conts/retrieving.html [or from the Cambridge Crystallographic Data Centre, 12, Union Road, Cambridge CB2 1EZ, UK; fax: (internat.) +44-1223/336-033; E-mail: deposit@ccdc.cam. ac.uk].

\section{Acknowledgements}

We sincerely thank Albemarle ${ }^{\circledR}$ Europe SPRL for a generous donation of $M A O$.

\section{References and Notes}

[1] a) M. Svoboda, H. tom Dieck, J. Organomet. Chem. 1980, 191, 321-328; b) G. van Koten, K. Vrieze, $A d v$. Organomet. Chem. 1982, 21, 151-239.

[2] a) L. K. Johnson, C. M. Killian, M. Brookhart, J. Am. Chem. Soc. 1995, 117, 6414-6415; b) L. K. Johnson, S. Mecking, M. Brookhart, J. Am. Chem. Soc. 1996, 118, $267-268$.

[3] See, for example: a) T. Schleis, T. P. Spaniol, J. Okuda, J. Heinemann, R. Mülhaupt, J. Organomet. Chem. 1998, 569, 159-167; b) S. A. Svejda, M. Brookhart, Organometallics 1999, 18, 65-74; c) T. V. Laine, M. Klinga, M. Leskelä, Eur. J. Inorg. Chem. 1999, 959-964; d) A. Köppl, H. G. Alt, J. Mol. Catal. A 2000, 154, 45-53; e) A. Held, S. Mecking, Chem. - Eur. J. 2000, 6, 4623-4629; f) M. Schmid, R. Eberhardt, M. Klinga, M. Leskelä, B. Rieger, Organometallics 2001, 20, 2321-2330; g) S. D. Ittel, L. K. Johnson, M. Brookhart, Chem. Rev. 2000, 100, 1169-204; h) V. C. Gibson, Chem. Rev. 2003, 103, 283316; i) S. Mecking, Coord. Chem. Rev. 2000, 203, 325351.

[4] a) J. C. Röder, F. Meyer, H. Pritzkow, Organometallics 2001, 20, 811-817; b) J. C. Röder, F. Meyer, E. Kaifer, Angew. Chem. 2002, 114, 2414-2417; Angew. Chem. Int. Ed. 2002, 41, 2304-2306; c) J. C. Röder, F. Meyer, R. F. Winter, I. Hyla-Kryspin, E. Kaifer, Chem. Eur. J. 2003, 9, 2636-2648; d) T. Sheng, S. Dechert, I. Hyla-Kryspin, R. F. Winter, F. Meyer, Inorg. Chem. 2005, 44, 3863-3874.

[5] a) F. Meyer, S. Beyreuther, K. Heinze, L. Zsolnai, Chem. Ber./Recueil 1997, 130, 605-613; b) F. Meyer, P. Rutsch, Chem. Commun. 1998, 1037-1038; c) F. Meyer, E. Kaifer, P. Kircher, K. Heinze, H. Pritzkow, Chem. Eur. J. 1999, 5, 1617-1630; d) J. Ackermann, F. Meyer, E. Kaifer, H. Pritzkow, Chem. Eur. J. 2002, 8, 247-258.

[6] a) B. Bauer-Siebenlist, F. Meyer, E. Farkas, D. Vidovic, J. A. C. Seijo, R. Herbst-Irmer, H. Pritzkow, Inorg. Chem. 2004, 43, 4189-4202; b) B. Bauer-Siebenlist, F. 
Meyer, E. Farkas, D. Vidovic, S. Dechert, Chem. Eur. J. 2005, 11, 4349-4360; c) B. Bauer-Siebenlist, S. Dechert, F. Meyer, Chem. Eur. J. 2005, 11, 5343-5352.

[7] J. C. Röder, F. Meyer, M. Konrad, S. Sandhöfner, E. Kaifer, H. Pritzkow, Eur. J. Org. Chem. 2001, 4479-4487.

[8] J. C. Röder, F. Meyer, H. Pritzkow, Chem. Commun. 2001, 2176-2177.

[9] a) G. Süss-Fink, Angew. Chem. 1994, 106, 71-73; Angew. Chem. Int. Ed. 1994, 33, 67; b) E. K. Van den Beuken, B. L. Feringa, Tetrahedron 1998, 54, 12985-13011; c) D. G. McCollum, B. Bosnich, Inorg. Chim. Acta 1998, 270, 13-19.

[10] a) J. T. Patton, T. J. Marks, L. Li (Dow Chemical Company), European Patent EP 1,015,462 B1, WO 99/014222, 1999; b) J. Wang, H. Li, N. Guo, C. L. Stern, T. J. Marks, Organometallics 2004, 23, 5112-5114; c) H. Li, C. L. Stern, T. J. Marks, Macromolecules 2005, 38, 9015-9027 and references cited therein.

[11] a) S. K. Noh, M. Lee, D. H. Kum, K. Kim, W. S. Lyoo, D.H. Lee, J. Polym. Sci., Part A 2004, 42, 1712-1723; b) M. Deppner, R. Burger, H. G. Alt, J. Organomet. Chem. 2004, 689, 1194-1211; c) M. H. Lee, S. K. Kim, Y. Do, Organometallics 2005, 24, 3618-3620.

[12] a) X. Mi, Z. Ma, L. Wang, Y. Ke, Y. Hu, Macromol. Chem. Phys. 2003, 204, 868-876; b) I. A. Guzei, K. Li, G. A. Bikzhanova, J. Darkwa, S. F. Mapolie, Dalton Trans. 2003, 715-722; c) X. Mi, Z. Ma, N. Cui, L. Wang, Y. Ke, Y. Hu, J. Appl. Polym. Sci. 2003, 88, 3273-3278; d) V. Lozan, P.-G. Lassahn, C. Zhang, B. Wu, C. Janiak, G. Rheinwald, H. Lang, Z. Naturforsch. 2003, 58b, 1152-1164; d) H.-K. Luo, H. Schumann, J. Mol. Catal. A 2005, 227, 153-161; e) S. Jie, D. Zhang, T. Zhang, W.-H. Sun, J. Chen, Q. Ren, D. Liu, G. Zheng, W. Chen, J. Organomet. Chem. 2005, 690, 1739-1749; f) T. Hu, L.-M. Tang, X.-F. Li, Y.-S. Li, N.-H. Hu, Organometallics 2005, 24, 2628-2632.

[13] L. Wolff, Liebigs Ann. Chem. 1902, 325, 186-192.

[14] V. J. Arán, M. Kumar, J. Molina, L. Lamarque, P. Navarro, E. García-España, J. A. Ramírez, S. V. Luis, B. Escuder, J. Org. Chem. 1999, 64, 6135-6146.

[15] V. I. Minkin, A. D. Garnovskii, J. Elguero, A. R. Katritzky, O. V. Denisko, Adv. Heterocyclic Chem. 2000, 76, 157-323.

[16] a) L. Deng, T. K. Woo, L. Cavallo, P. M. Margl, T. Ziegler, J. Am. Chem. Soc. 1997, 119, 6177-6186; b) R. D. J. Froese, D. G. Musaev, K. Morokuma, J. Am. Chem. Soc. 1998, 120, 1581-1587; c) T. K. Woo, T. Ziegler, J. Organomet. Chem. 1999, 591, 204-213; d) A. Michalak, T. Ziegler, Organometallics 2000, 19, 1850-1858.
[17] a) T. Schleis, T. P. Spaniol, J. Okuda, J. Heinemann, R. Mulhaupt, J. Organomet. Chem. 1998, 569, 159-167; b) F. AlObaidi, Z. Ye, S. Zhu, Polymer 2004, 45, 68236829.

[18] a) M. Schmid, R. Eberhardt, M. Klinga, M. Leskelä, B. Rieger, Organometallics 2001, 20, 2321-2330; b) N. M. Comerlato, G. L.Crossetti, R. A. Howie, P. C. D. Tibultino, J. L. War, Acta Cryst. 2001, E57, m295-m297.

[19] a) T. V. Laine, U. Piironen, K. Lappalainen, M. Klinga, E. Aitola, M. Leskelä, J. Organomet. Chem. 2000, 606, 112-124; b) T. V. Laine, M. Klinga, M. Leskelä, Eur. J. Inorg. Chem. 1999, 959-964.

[20] For some related nickel(II) and palladium(II) complexes with pyridylimine ligands, see: a) V. C. Gibson, C. M. Halliwell, N. J. Long, P. J. Oxford, A. M. Smith, A. J. P. White, D. J. Williams, Dalton Trans. 2003, 918-926; b) A. Köppl, H. G. Alt, J. Mol. Catal A: Chem. 2000, 154, 45-53; c) S. P. Meneghetti, P. J. Lutz, J. Kress, Organometallics 1999, 18, 2734-2737.

[21] M. Kang, A. Sen, L. Zakharov, A. L. Rheingold, J. Am. Chem. Soc. 2002, 124, 12080-12081.

[22] a) S. Trofimenko, Progr. Inorg. Chem. 1986, 34, 115-210; b) G. La Monica, G. A. Ardizzoia, Progr. Inorg. Chem. 1997, 46, 151-238; c) A. L. Gavrilova, B. Bosnich, Chem. Rev. 2004, 104, 349-383; c) M. Konrad, S. Wuthe, F. Meyer, E. Kaifer, Eur. J. Inorg. Chem. 2001, $2233-$ 2240.

[23] a) H. Lee, C. B. Knobler, M. F. Hawthorne, J. Am. Chem. Soc. 2001, 123, 8543-8549; b) F. Hezel, D. Fenske, J. Eisenmann, T. Wetzel, Z. Anorg. Allg. Chem. 2000, 626, 290-301; c) T. Alsina,W. Clegg, K. A. Fraser, J. Sola, J. Chem. Soc. Chem. Commun. 1992, 1010-1011; d) V. B. Shur, I. A. Tikhonova, A. I. Yanovsky, Yu. T. Struchkov, P. V. Petrovskii, S. Yu. Panov, G. G. Furin, M. E. Vol'pin, J. Organomet. Chem. 1991, 418, C29-C32.

[24] D. P. Gates, S. A. Svejda, E. Onate, C. M. Killian, L. K. Johnson, P. S. White, M. Brookhart, Macromolecules 2000, 33, 2320-2334.

[25] G. M. Sheldrick, SHELXL-97, Program for Crystal Structure Refinement, Universität Göttingen, 1997; G. M. Sheldrick, SHELXS-97, Program for Crystal Structure Solution, Universität Göttingen, 1997.

[26] G. M. Sheldrick, SADABS Program for Empirical Absorption Correction of Area, Universität Göttingen, 1997.

[27] STOE \& CIE GmbH, $X$-RED, Darmstadt, 2002.

[28] P. v. d. Sluis, A. L. Spek, Acta Crystallogr. 1990, A46, 194-201.

[29] A. L. Spek, PLATON, A Multipurpose Crystallographic Tool, Utrecht University, 2003. 